\title{
Computerondersteund samenwerkend leren in het coschap Sociale Geneeskunde
}

\author{
R.F.M. Turk, M.E.W. Dankbaar, E.F. van Beeck
}

\begin{abstract}
Samenvatting
Inleiding: Ter bevordering van het samenwerkend leren is in het coschap Sociale Geneeskunde, waar coassistenten geïsoleerd van elkaar en van de centrale docenten stage lopen, het Computer Ondersteund Leren (Computer Supported Collaborative Learning, CSCL) geïntroduceerd en geëvalueerd.
\end{abstract}

Methoden: We ontwikkelden een digitaal platform voor subgroepen van coassistenten die niet alleen gezamenlijk een praktijkgericht probleem in korte tijd evidence-based moeten uitwerken tot een publicatie maar ook moeten verdedigen. Daarnaast werd elke coassistent gevraagd een individuele peer review te geven op de publicatie van een andere subgroep. Aan de hand van een schriftelijke vragenlijst evalueerden we in twee verschillende fasen de ervaringen van 141 studenten.

Resultaten: 124 (88\%) coassistenten retourneerden de vragenlijst. $65 \%$ van de respondenten vond de aangeboden probleemstellingen interessant. De samenwerking binnen de groep werd als goed (94\%) en gelijkwaardig (90\%) ervaren. De helft gaf aan geleerd te hebben van de samenwerking en tweederde gaf aan te hebben geleerd van het geven (63\%) en ontvangen (64\%) van een peer review.

In de eerste fase waardeerde slechts 33\% de digitale leeromgeving als positief. Met de introductie van wiki's in de tweede fase steeg dit percentage naar 49\%. Aanvullende opmerkingen werden gemaakt over het tijdschema, de grootte en helderheid van de opdrachten en het digitale leerplatform. Per student werd gemiddeld tien uur per week aan de uitwerking van de opdracht besteed.

Discussie en conclusie: CSCL kan bijdragen aan samenwerkend en zelfsturend leren in die situaties waarin studenten gescheiden zijn van elkaar en van hun docenten. Het leren van samenwerken kan hierin nog verder worden gestimuleerd. De setting, het gebruikersgemak en het moment van introductie van de digitale leeromgeving zijn medebepalend voor de tevredenheid. (Turk RFM, Dankbaar MEW, Beeck EF van. Computerondersteund samenwerkend leren in het coschap Sociale Geneeskunde. Tijdschrift voor Medisch Onderwijs 2009;28(6):269-279.)

\section{Inleiding}

Binnen de opleiding Geneeskunde van het Erasmus Medisch Centrum (MC) is het coschap Sociale Geneeskunde een twee weken durend coschap dat als een-na-laatst regulier coschap moet worden doorlopen. Binnen dit coschap wordt naar keuze stage gelopen bij ouder-, kind- en thuiszorginstellingen en bij verslavingszorg, arbodiensten, GGD en het UWV.
Opleiding en training van een coassistent binnen de coschappen vindt meestal plaats op individuele basis waarbij een of meerdere opleiders ter plaatse zijn betrokken. In sommige coschappen, bijvoorbeeld binnen het coschap Sociale Geneeskunde, kan de afstand tussen twee individuele coassistenten zelfs meer dan honderd kilometer bedragen waardoor de onderlinge contacten en samenwerking, die bijvoorbeeld nodig 


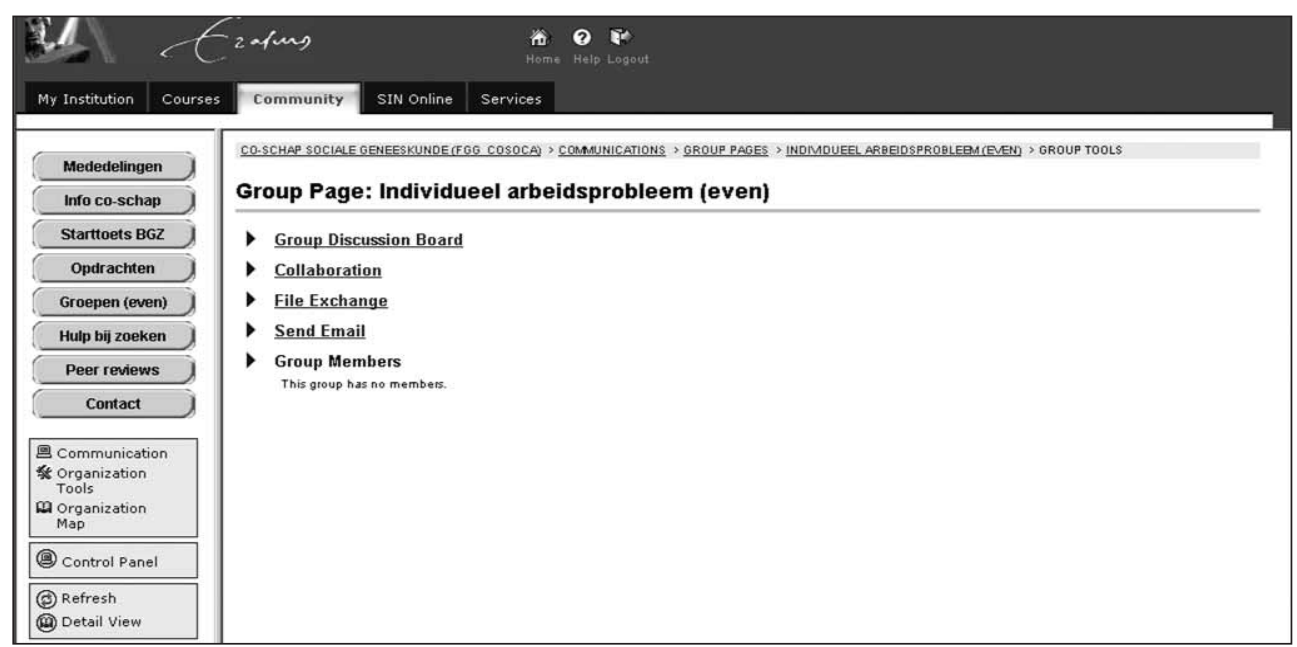

Figuur 1. Het groepsdomein op de digitale leeromgeving. Het groepsleerdomein bestond uit een communicatieplatform (deze figuur) en een wiki. Via het communicatieplatform konden coassistenten binnen hun groep onderling discussiëren en gegevens uitwisselen; op de wiki werd het uiteindelijke product gemaakt.

zijn om van elkaar te kunnen leren, worden bemoeilijkt.

De binnen de opleiding geïntroduceerde CanMEDS competenties beschrijven zeven groepen van beoordelingscriteria waarop een (aankomend) arts getoetst kan worden. ${ }^{1}$ Deze competenties omvatten onder meer de dagelijks benodigde intra- en interdisciplinaire samenwerking, de afstemming en overeenstemming ter bevordering van kwaliteit van handelen en conflictoplossing, het up-to-date houden van de inzichten in de medische kennis en wetenschap en het wegen van de maatschappelijke belangen in het medisch handelen. Gezien de onderlinge fysieke afstand tussen de coassistenten en de wens binnen het coschap Sociale Geneeskunde van het Erasmus MC deze CanMEDS competenties te stimuleren en beter te kunnen beoordelen, is een digitaal platform ontwikkeld zodat coassistenten op afstand van elkaar digitaal kunnen samenwerken aan de evidence-based uitwerking van een praktijkgerelateerd (maatschappelijk) probleem.
In deze publicatie beschrijven wij de ontwikkeling, opzet, implementatie en evaluatie van een vorm van Computer Supported Collaborative Learning (CSCL) die we hebben toegepast in ons coschap Sociale Geneeskunde van het Erasmus MC, in de hoop ideeën aan te reiken die ook in andere coschappen samenwerkend leren in de medische opleiding zullen bevorderen. ${ }^{2}$

\section{Methode \\ Ontwerp eerste fase}

$\mathrm{Na}$ de verdeling van de stageplaatsen over de coassistentengroep van gemiddeld 14 studenten werden binnen twee stagerichtingen (elk met ongeveer acht stageplaatsen) op vrijwillige basis subgroepjes van drie tot vijf coassistenten gevormd. Het betrof de stagerichtingen Arbeid en Gezondheid (bedrijfsgeneeskunde en verzekeringsgeneeskunde) respectievelijk Maatschappij en Gezondheid (GGD, ouder- en kindzorginstellingen, verslavingszorg, thuiszorg). Binnen de bestaande digitale leeromgeving $\left(\right.$ Blackboard $^{\circledR}$ ) werd voor elke subgroep een 
Box 1. Overzicht probleemstellingen voor de stages.

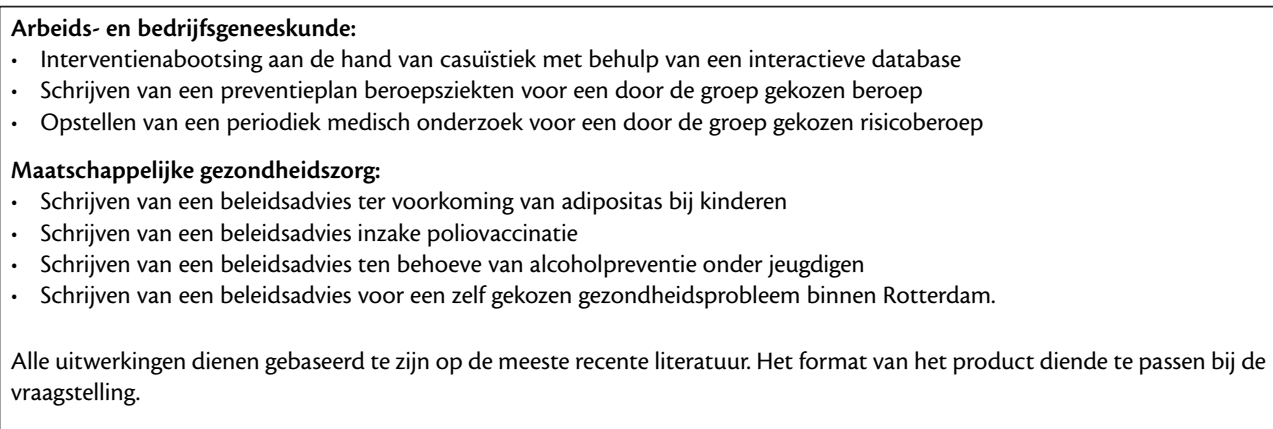

werkruimte aangemaakt waarbinnen de coassistenten konden chatten, mailen en bestanden uitwisselen (zie Figuur 1).

We ontwikkelden zeven op de praktijk gebaseerde probleemstellingen waaruit de subgroepen coassistenten een aan hun stagerichting verwante opdracht konden kiezen (zie Box 1). Daarnaast werd de mogelijkheid geboden zelf, onder voorwaarden van aansluiting bij het vakgebied en geschiktheid voor samenwerking, een opdracht in te brengen. Hierbij werd gelet op de (maatschappelijke) relevantie van de opdracht en de grootte en uitwerkbaarheid van het probleem ten opzichte van de lengte van het coschap en de groepsgrootte. Elke subgroep diende een opdracht te kiezen, schriftelijk uit te werken en te verdedigen op de slotmiddag van het coschap. Als voorbereiding op de verdediging moest iedere coassistent een individuele peer review geven op de schriftelijke uitwerking van een andere subgroep.

In het licht van de CanMEDS competenties werden criteria opgesteld voor onder meer de beoordeling van de (onderbouwing van de) uitwerking, de kwaliteit van de peer review, de mondelinge verdediging en de samenwerking (zie Tabel 1). ${ }^{1} \mathrm{Om}$ binnen de korte duur van het coschap het gehele proces te stroomlijnen werd een tijdschema voor de schriftelijke uitwerking, de peer review en de verdediging opgesteld.
Dit schema en de ondersteunende achtergrondinformatie over het samenwerken werden op papier uitgereikt tijdens de gezamenlijke werkcolleges op de startdag van een groep coassistenten. Beoordelingscriteria voor de uitwerking van de opdracht en een format voor het geven van een peer review werden online aangeboden (zie Tabel 2).

Binnen het twee weken durende coschap Sociale Geneeskunde diende elke subgroep binnen een periode van negen dagen een evidence-based uitwerking te schrijven van mogelijke oplossingen bij de gekozen probleemstelling. Hierna had elke individuele coassistent 36 uur de tijd voor het geven van een schriftelijke peer review op de uitwerking van een andere subgroep uit de eigen coassistentengroep. Binnen 24 uur na ontvangst van alle peer reviews werd elke subgroep in de slotbijeenkomst gevraagd de uitwerking ten overstaan van de docenten en de gehele coassistentengroep te verdedigen. Het maken van afspraken over onderlinge samenwerking werd overgelaten aan de subgroepen zelf. Indien nodig verzorgde het Erasmus MC voor de coassistenten een laptop met internetaansluiting, bijvoorbeeld bij een overnachting in een hotel.

De uiteindelijke schriftelijke uitwerking, de onderlinge samenwerking, de verdediging en de kwaliteit van de gegeven peer review 
Tabel 1. De gebruikte CanMEDS competenties.

\begin{tabular}{lll}
\hline CanMEDS competenties & Onvoldoende & Voldoende \\
\hline
\end{tabular}

\section{Medisch expert}

De coassistent toont en integreert op positieve en effectieve wijze alle omschreven CanMEDS rollen

De coassistent zoekt adequate samenwerking met andere coassistenten en medische professionals, de eigen grenzen van de expertise wetend

\section{Communicatie}

De coassistent ontwikkelt consensus in het creëren van oplossingen en plannen in overleg met andere coassistenten en medische professionals

De coassistent is zowel mondeling als schriftelijk effectief en professioneel in staat informatie over medische problematiek over te brengen

\section{Samenwerking}

De coassistent werkt effectief en adequaat samen in een team

De coassistent werkt effectief met andere coassistenten en medische professionals samen om in overleg conflicten te voorkomen en op te lossen

\section{Organisatie}

De coassistent neemt deel aan activiteiten die de effectiviteit van de groep waarin samen wordt gewerkt bevordert

\section{Maatschappelijk handelen}

De coassistent staat open voor en handelt naar de gesignaleerde medische vraag van een populatie waarbinnen zorg wordt verleend

De coassistent is in staat gezondheidsproblemen te herkennen binnen een populatie waarbinnen zorg wordt verleend

Het handelen van de coassistent is gericht op het bevorderen van de gezondheid van individuele patiënten, gemeenschappen en populaties

\section{Kennis en wetenschap}

De coassistent is in staat informatie naar inhoud en oorsprong kritisch te beoordelen en adequaat toe te passen in de praktijk

De coassistent bevordert en neemt op positieve wijze deel aan het leren van andere coassistenten en medische professionals

De coassistent draagt waar mogelijk bij aan de ontwikkeling van (nieuwe) inzichten in de medische kennis en wetenschap van zichzelf en anderen

\section{Professional}

De coassistent laat door attitude en inspanning betrokkenheid met patiënten, beroep en maatschappij zien 
Tabel 2. Het in de eerste en tweede fase gebruikte format voor het geven van een peer review.

\begin{tabular}{l}
\hline Checklist peer review \\
\hline Analyse van het probleem: Is het plan gebaseerd op een adequaat uitgevoerde \\
analyse van het probleem? Is de kern duidelijk? \\
Strategie: Richt het plan zich op de belangrijkste oorzakelijke factoren van \\
het probleem? \\
Effectiviteit: Wordt er in het plan gebruik gemaakt van interventies die een \\
bewezen effectiviteit hebben? Worden eventueel bestaande richtlijnen \\
adequaat toegepast in het plan? \\
Haalbaarheid: Wordt er in het plan voldoende aandacht besteed aan \\
haalbaarheid (financieel en politiek) en mogelijke belemmeringen bij de \\
uitvoering? Wordt er in mogelijke oplossingen voorzien? \\
Geraadpleegde bronnen: Is adequat gebruik gemaakt van beschikbare \\
informatie uit de praktijk? En van beschikbare wetenschappelijke informatie? \\
Goede referenties? \\
Structuur en leesbaarheid: Is het plan helder qua opzet en goed leesbaar? \\
Bijzondere punten/ Suggesties ter verbetering
\end{tabular}

werden door de docenten beoordeeld. Deze beoordelingen telden gezamenlijk voor $40 \%$ mee in de eindbeoordeling van het coschap.

\section{Onderzoekspopulatie en variabelen eerste fase}

Vijf opeenvolgende groepen coassistenten van het Erasmus MC $(n=75)$ werd na afsluiting van het coschap met behulp van open en multiple choice vragen schriftelijk gevraagd de opdracht, groepsatmosfeer, samenwerking, peer review, digitale platform en het bestede aantal uren te evalueren. Daarnaast werd in een open vraag geïnformeerd naar mogelijke verbeteringen van de opzet.

\section{Ontwerp tweede fase}

In reactie op de evaluatie van coassistenten uit de eerste fase introduceerden wij wiki's binnen het digitale platform met als doel de onderlinge samenwerking aan slechts één document te bevorderen en problemen met verschillende versies van een uitwerking te vermijden. Een wiki is een applicatie of (web)toepassing waarmee men webdocumenten gezamenlijk kan bewerken. Een bekend voorbeeld van een wiki is Wikipedia, de digitale internetencyclopedie die vrijelijk door een ieder kan worden aangepast (zie voor uitleg: nl.wikipedia.org/wiki/wiki en www.leren.nl/artikelen/2004/wiki.html). Binnen deze wiki's, te vergelijken met een wiki als wikipedia, kreeg iedere individuele coassistent de gelegenheid om binnen een voor de groep toegankelijke webpagina teksten of afbeeldingen toe te voegen, aan te passen of te verwijderen. Doordat alle individuele handelingen op de wiki bewaard en inzichtelijk bleven voor de docenten konden deze een beter inzicht krijgen in het verloop van de ontwikkeling van het product en de onderlinge samenwerking (zie Figuur 2).

Op suggestie van de coassistenten uit de eerste fase voerden wij minimale veranderingen in het opgelegde tijdschema door voor de ontwikkeltijd van de publicatie (tien 


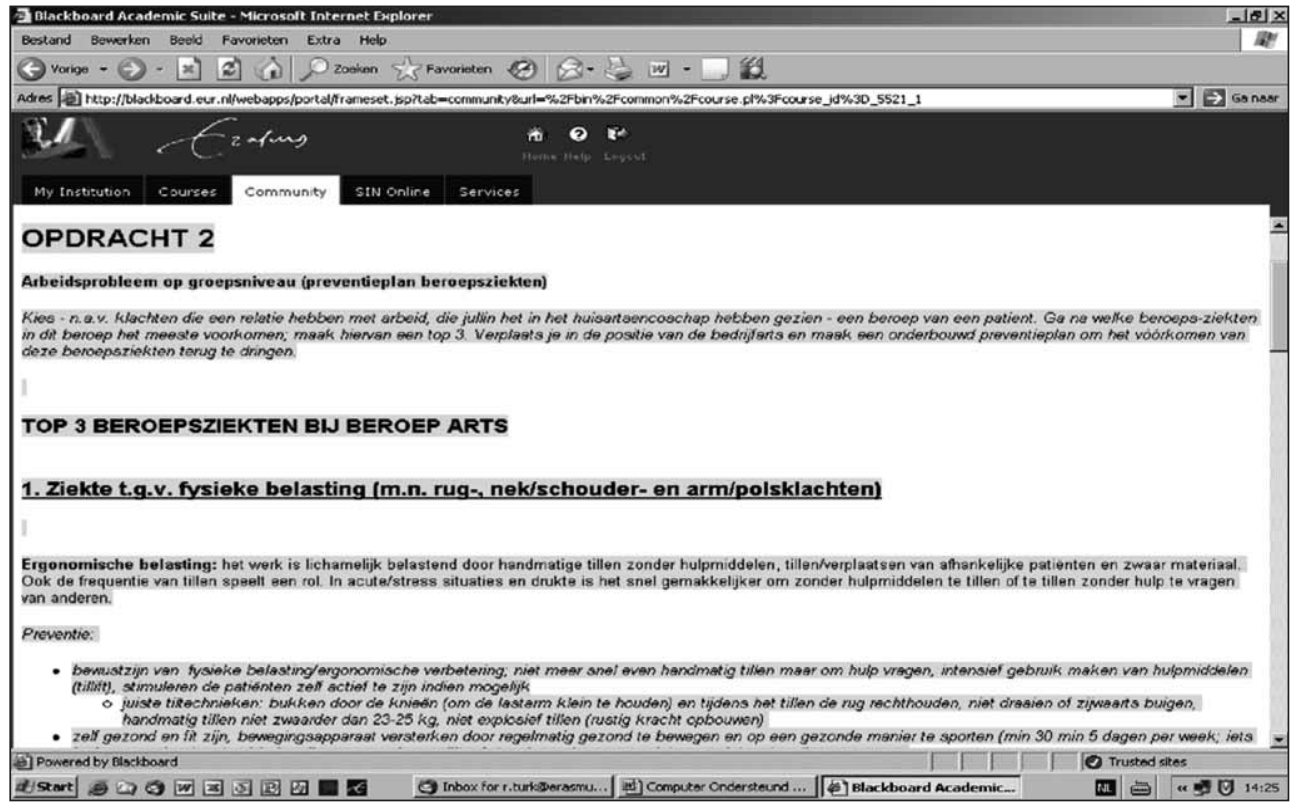

Figuur 2. Voorbeeld van procesinformatie voor de docent. Voor docenten zijn alle verrichte handelingen op individueel niveau zichtbaar te maken. In dit figuur is de gearceerde tekst door deze coassistent in inlogsessie $n r$ 2 toegevoegd aan de wiki.

in plaats van negen dagen), werden enkele dagdelen vrij geroosterd voor de uitwerking van de opdracht en is besloten de tijd voor het geven van een peer review te beperken tot 24 uur.

Op basis van de evaluatiegegevens werd ook besloten in de tweede fase geen schriftelijke informatie over samenwerken te verstrekken.

\section{Onderzoekspopulatie en variabelen tweede fase}

Wederom werden vijf opeenvolgende coassistentengroepen $(n=66)$ schriftelijk gevraagd de opzet te evalueren. Op grond hiervan werden in de vragenlijst kleine wijzigingen aangebracht en werd een evaluatie van het werken met de wiki opgenomen.

\section{Resultaten}

\section{Resultaten eerste fase}

In de eerste fase ontvingen wij $89 \%$ van de vragenlijsten retour $(n=67)$. Niet alle vragen waren volledig ingevuld. $68 \%$ van de respondenten vond de aangeboden probleemstellingen interessant. De samenwerking binnen de groep werd door bijna alle coassistenten als goed (97\%) en gelijkwaardig $(95 \%)$ ervaren. Men gaf aan geleerd te hebben van de samenwerking (55\%) en van het geven $(63 \%)$ en ontvangen $(69 \%)$ van een peer review. De digitale leeromgeving, de te verkrijgen informatie, de opdrachten, de groepsomgeving, het forum en weblinks als geheel, werden door slechts 33\% positief gewaardeerd (Zie Tabel 3a).

Aanvullende opmerkingen konden verdeeld worden in drie hoofdcategorieën: het opgelegde tijdschema en de grootte van de opdrachten in relatie tot de duur 
Tabel 3a. Evaluatieresultaten eerste fase.

\begin{tabular}{|c|c|c|c|c|}
\hline \multirow[b]{2}{*}{ Vraagstelling: } & \multirow[b]{2}{*}{ Respons } & \multicolumn{3}{|c|}{$\begin{array}{l}\text { Fase } 1, n=75 \\
\text { Respons } 89 \%(67)\end{array}$} \\
\hline & & $\%+$ & $\%-$ & $\% 0$ \\
\hline De aangeboden opdrachten waren interessant & 63 & 68 & 2 & 30 \\
\hline De sfeer in de groep was goed & 64 & 97 & 3 & 0 \\
\hline De onderlinge samenwerking verliep gelijkwaardig & 64 & 95 & 2 & 3 \\
\hline In de samenwerking heeft men (veel) van elkaar geleerd & 64 & 55 & 11 & 34 \\
\hline De tips voor groepssamenwerking waren bekeken & 64 & 34 & 66 & \\
\hline De tips voor groepssamenwerking werden positief gewaardeerd & 22 & 55 & 45 & \\
\hline Het geven van een peer review was leerzaam & 64 & 63 & 30 & 6 \\
\hline Het krijgen van een peer review was leerzaam & 64 & 69 & 26 & 4 \\
\hline De aangeboden digitale leeromgeving werd positief gewaardeerd & 61 & 33 & 51 & 16 \\
\hline De gemiddelde tijdsbesteding aan de opdracht bedroeg per student & 66 & \multicolumn{3}{|c|}{$10 u(3-40 u)$} \\
\hline
\end{tabular}

van het coschap (56\%), het gebrek aan duidelijkheid in de vraagstelling van sommige opdrachten $(16 \%)$ en opmerkingen over de digitale leeromgeving, zoals het ontbreken van een duidelijke meerwaarde van de leeromgeving naast de al bestaande digitale mogelijkheden als internet en e-mail en het moment van introductie van de leeromgeving $(13 \%)$. De mediane en gemiddelde tijd die de student aan de uitwerking van de opdracht besteedde bedroeg tien uur.

\section{Resultaten tweede fase}

In de tweede fase ontvingen wij $86 \%$ van de vragenlijsten retour $(n=57)$. Ook in deze fase waren niet alle vragen volledig ingevuld. $61 \%$ van de respondenten vond de aangeboden probleemstellingen interessant. De samenwerking binnen de groep werd als goed $(91 \%)$ en gelijkwaardig $(84 \%)$ ervaren, waarbij moet worden aangetekend dat deze cijfers nadelig zijn beïnvloed door problemen in de samenwerking rondom één persoon binnen een specifieke subgroep. Ten opzichte van de eerste fase gaf een kleiner deel aan geleerd te hebben van de samenwerking (38\%) en van het geven $(63 \%)$ en ontvangen $(59 \%)$ van een peer review. De waardering van de digitale leeromgeving steeg naar 49\% ondanks het feit dat de wiki door slechts 34\% positief werd gewaardeerd (zie Tabel 3b).

Studenten gaven aan het meest geleerd te hebben van het uitwerken van sociaal geneeskundige vraagstukken $(68 \%)$ en van het evidence-based zoeken naar literatuur (21\%). $12 \%$ had het geven en ontvangen van peer reviews als meest leerzaam ervaren. Aanvullende opmerkingen konden wederom verdeeld worden in drie hoofdcategorieën: het opgelegde tijdschema en de grootte van de opdrachten in relatie tot de duur van het coschap (37\%), het gebrek aan duidelijkheid in de vraagstelling van sommige opdrachten (24\%) en de beperkingen (met name opmaak- en transferproblemen van tekst naar de wiki) en het moment van introductie van de verzorgde digitale leeromgeving (5\%). De gemiddeld bestede tijd per student bedroeg 10.4 uur, de mediaan 9.6 uur. 
Tabel 3b. Evaluatieresultaten tweede fase.

\begin{tabular}{lcccc}
\hline & & \multicolumn{2}{c}{$\begin{array}{c}\text { Fase 2, } \mathrm{n}=66 \\
\text { Respons 86\% (57) }\end{array}$} \\
\hline Vraagstelling: & \multicolumn{1}{c}{ Respons } & $\%+$ & $\%-$ & $\% 0$ \\
\hline De aangeboden opdrachten waren interessant & 57 & 61 & 7 & 32 \\
De sfeer in de groep was goed & 57 & 91 & 7 & 2 \\
De onderlinge samenwerking verliep gelijkwaardig & 57 & 84 & 11 & 5 \\
In de samenwerking heeft men (veel) van elkaar geleerd & 57 & 38 & 31 & 31 \\
Het geven van een peer review was leerzaam & 56 & 63 & 34 & 4 \\
Het krijgen van een peer review was leerzaam & 56 & 59 & 37 & 4 \\
De aangeboden digitale leeromgeving werd positief gewaardeerd & 56 & 49 & 23 & 28 \\
Het gebruik van de wiki werd positief gewaardeerd & 56 & 34 & 30 & 36 \\
De handleiding bij de wiki was gelezen & 53 & 85 & 15 & 24 \\
De handleiding bij de wiki was duidelijk & 48 & 76 & 24 \\
De gemiddelde tijdsbesteding aan de opdracht bedroeg per student & 52 & $10.4 \mathrm{u}(4-30 \mathrm{u})$ \\
\hline
\end{tabular}

Tabel 3c. Evaluatieresultaten en totaaloverzicht.

\begin{tabular}{|c|c|c|c|c|}
\hline \multirow[b]{2}{*}{ Vraagstelling: } & \multicolumn{4}{|c|}{$\begin{array}{c}\text { Fase } 2, n=141 \\
\text { Respons } 88 \%(124)\end{array}$} \\
\hline & Respons & $\%+$ & $\%-$ & $\% 0$ \\
\hline De aangeboden opdrachten waren interessant & 120 & 65 & 4 & 31 \\
\hline De sfeer in de groep was goed & 121 & 94 & 5 & 1 \\
\hline De onderlinge samenwerking verliep gelijkwaardig & 121 & 90 & 6 & 4 \\
\hline In de samenwerking heeft men (veel) van elkaar geleerd & 121 & 48 & 20 & 32 \\
\hline Het geven van een peer review was leerzaam & 120 & 63 & 32 & 5 \\
\hline Het krijgen van een peer review was leerzaam & 120 & 64 & 32 & 4 \\
\hline De aangeboden digitale leeromgeving werd positief gewaardeerd & 117 & 41 & 37 & 22 \\
\hline De gemiddelde tijdsbesteding aan de opdracht bedroeg per student & 118 & \multicolumn{3}{|c|}{$10.2 u(3-40 u)$} \\
\hline
\end{tabular}

\section{Resultaten algemeen}

In twee fasen evalueerden wij onder 141 coassistenten de inzet van Computer Supported Collaborative Learning (CSCL) binnen het coschap Sociale Geneeskunde van het Erasmus MC. Wij ontvingen over de twee fasen als totaal 124 vragenlijsten retour $(88 \%)$. De resultaten van de gehele pilot staan vermeld in Tabel 3c.
Tweederde van de respondenten vond de aangeboden probleemstellingen interessant. De samenwerking binnen de groep werd in bijna alle gevallen als goed en gelijkwaardig ervaren. Slechts de helft van de respondenten gaf aan geleerd te hebben van de samenwerking en tweederde had geleerd van het geven en ontvangen van een peer review. Aanvullende opmerkingen werden gemaakt over het opge- 
legde tijdschema en de grootte van de opdrachten in relatie tot de duur van het coschap, het gebrek aan duidelijkheid van sommige opdrachten en de beperkingen van de verzorgde digitale leeromgeving. De gemiddeld bestede tijd bedroeg tien uur per coassistent.

\section{Discussie en conclusie}

\section{Kanttekeningen bij de evaluatie}

Dit onderzoek had niet tot doel de verschillende varianten van onderwijs naast elkaar te zetten en de mogelijke leereffecten of verschillen in voldoening te vergelijken. Ook hebben wij geen vergelijking gemaakt met voorgaande groepen zonder CSCL. Binnen de literatuur is voldoende discussie te vinden over de voor- en nadelen van CSCL in vergelijking met hoorcolleges of andere vormen van onderwijs. In onze opzet was CSCL geen vervanging van bestaand onderwijs maar een aanvulling op de al bestaande werkcolleges en verving CSCL eerdere individuele leeropdrachten binnen het coschap door een samenwerkingsgerichte groepsopdracht. ${ }^{3}$

Als een na laatste coschap binnen het reguliere coschappenschema is een introductie van een nieuwe leermethode vrijwel altijd lastig. Geen van de ondervraagde coassistenten had ervaring in het werken met wiki's en veel opmerkingen werden dan ook gemaakt over het hoe en waarom van deze introductie in de laatste fase van de opleiding. Er was zogezegd sprake van een (forse) weerstand onder coassistenten om in deze fase nog te moeten leren werken met iets waarmee ze later in hun carrière waarschijnlijk niet meer te maken zouden krijgen. Opvallenderwijs steeg de tevredenheid over de digitale leeromgeving in de tweede fase naar 49\% en dat terwijl slechts $34 \%$ het gebruik van de wiki positief waardeerde en er verder geen veranderingen in de leeromgeving waren aangebracht. Onze gegevens bieden hier geen verklaring voor. Derdejaarsstudenten geneeskunde van het Erasmus MC die sinds een paar jaar al wel bekend zijn met dezelfde wikistructuur zijn tot op heden nog niet tot ons coschap doorgedrongen. Mogelijk dat onder deze groep de evaluatie positiever zou uitvallen.

In aanvulling op de weerstand tegen het moeten leren werken met een wiki ontdekten wij in de mondelinge evaluaties met de coassistenten ook een mate van weerstand tegen de nieuwe leervorm als geheel. De in de regel lage interesse in het vakgebied van de sociale geneeskunde in combinatie met de vorm van het nieuwe onderwijs, waarin coassistenten zelf actief en samenwerkend moeten leren, waren naar onze inschatting debet hieraan. ${ }^{4}$ Maar het eerste half jaar na de introductie van deze nieuwe leervorm werd de weerstand, zoals geuit bij de mondelinge evaluaties op de slotmiddagen, geleidelijk minder. Op grond van deze mondelinge reacties van de studenten is onze inschatting dat vandaag de dag de nieuwe leervorm wel geaccepteerd is.

Belangrijke factoren die mede bepalend waren voor de positieve waarderingen in de pilot waren onder meer de kwaliteit van de geboden opdrachten, het ontwikkelde format voor het geven van een peer review, de heldere beoordelingscriteria, het werken in zelf gekozen kleine en bekende groepjes en de combinatie van face-to-face onderwijs (hoorcolleges) met digitaal samenwerkend leren. Vraag blijft natuurlijk waarom slechts de helft van de coassistenten aangeeft iets te hebben geleerd van de samenwerking, terwijl het ontvangen en geven van een peer review hoger scoort. Het idee dat mogelijk onderlinge samenwerking nog te onwennig is en misschien te weinig binnen de opleiding is geïntegreerd kan door het ontbreken van gegevens niet worden onderbouwd. Het onderzoek door Saab et al. leert echter wel dat 
meer aandacht voor de opzet en voorwaarden voor samenwerking naar de studenten toe ook een betere samenwerking tot stand brengt. ${ }^{5}$ Wij hadden hieraan in onze opzet meer aandacht kunnen besteden, maar vertrouwden wellicht iets te veel op de professionaliteit van de 'bijna' basisartsen.

Punt van discussie blijft de vraag waarom ook de tweede opzet van de digitale leeromgeving door slechts de helft van de ondervraagden als positief werd ervaren. Aan de voorwaarden voor CSCL, zoals gesteld door Van Eijl en Pilot, is in de gekozen opzet zo goed als voldaan, hoewel de interactieve mogelijkheden van het platform volgens de gebruikers te wensen overlieten en konden worden verbeterd met het aanbrengen van betere mogelijkheden tot interactie en gelijktijdig bewerken van de inhoud van de webpagina. ${ }^{6}$ In de verdere ontwikkelingsstappen van de opzet zal deze kritiek worden meegenomen.

De spreiding in het bestede aantal uren per student ( 3 - 40 uur) kan door ons niet worden verklaard. Ook zijn uit de anonieme schriftelijke evaluaties geen gegevens te destilleren over de tijdsbesteding per groep maar geven ons wel inzicht in de tevredenheid over de onderlinge samenwerking en werkverdeling, welke slechts bij één groep niet goed was. In de mondelinge evaluaties op de slotmiddagen daarentegen werd soms duidelijk dat taken en inbreng onderling verdeeld waren en dat studenten bijvoorbeeld als eindredacteur of hoofdverdediger waren aangewezen. Mogelijk dat deze taakverdeling ook voor de grote mate van spreiding in bestede uren heeft gezorgd, maar dit kan niet met kwantitatieve gegevens onderbouwd worden.

\section{Implicaties voor de praktijk}

Ondanks het feit dat de evaluatie beperkt is tot een tevredenheidsonderzoek onder de coassistenten en op een paar punten verbetering behoeft, zien wij als winst- punt van deze opzet de mogelijkheid om coassistenten ook op afstand van elkaar te kunnen laten leren. In de door ons gekozen opzet kan deze leervorm een welkome aanvulling zijn op de reeds bestaande leervormen waarin meer face-to-face contact plaatsvindt en kan het een breder kader van uitdagingen bieden dan de individuele e-learning modules.

De inzet van praktijkgerelateerde opdrachten kan ook voor de onderwijsinstelling zelf positieve effecten hebben. Aan de ene kant houdt de keuze van vrije onderwerpen docenten scherp en betrokken, aan de andere kant kan de deskundigheid en inzet van coassistenten worden benut om de organisatie verder te helpen. Zo hebben wij in de periode na de beschreven pilot in dezelfde opzet, en onder deskundige begeleiding, twee afzonderlijke groepen coassistenten een onderzoek naar de aanwezige binnenklimaatklachten in ons eigen gebouw laten verrichten. De resultaten en adviezen van dit gefaseerde onderzoek worden momenteel gebruikt in de aanpak van deze problemen. De betrokken coassistenten hebben aangegeven het leerzaam en leuk te hebben gevonden om een relevant praktijkprobleem aan te pakken en willen graag op de hoogte worden gehouden van de gevolgen van hun inspanningen.

Vragen die in de toekomst nader uitgezocht moeten worden zijn ondermeer de vragen die samenhangen met de voldoening van de leeromgeving en hoe deze kan worden verbeterd. Daarnaast, mede ondersteund door ernstige problemen in de samenwerking binnen één groep, vragen wij ons af of samenwerking binnen de opleiding geneeskunde niet meer moet worden gepromoot door dergelijke projecten, al of niet digitaal ondersteund. Wanneer je binnen de CanMEDS competenties op samenwerking toetst moet je samenwerking ook faciliteren. Geneeskundige zorg geef je tenslotte zelden alleen. 


\section{Literatuur}

1. Frank JR (Ed.). The CanMEDS 2005 physician competency framework. Better standards. Better physician.s. Better care. Ottawa: The royal College of Physicians and Surgeons of Canada; 2005.

2. Rubens W. Samenwerkend leren met behulp van ICT. In: PRJ Simons: Didactiek van digitaal leren. Tilburg: Studiehuisreeks; 2002(50):19-27. [Collaborative learning with ICT. The didactics of digital learning. Study House series; 2002(50):19-27].

3. Cook DA, Levinson AJ, Garside et al.: Internetbased learning in the health professions: a metaanalysis. JAMA 2008; 300(10):1181-1196.

4. Soethout MBM. Career preference of medical students and career choice of recent graduates. Wageningen: Ponsen \& Looyen BV; 2007.

5. Saab N, Joolingen WR van, Hout-Wolters BHAM van. Supporting communication in a collaborative discovery learning environment: the effect of instruction. Instructional Science: 2007(35):73-98.

6. Eijl P van, Pilot A. Succesfactoren bij het gebruik van een elektronische leeromgeving (ELO) bij samenwerkend leren. Onderzoek naar onderwijs 2002; 31(2/3):38-42. [Successfactors in the use of an electronic learning environment (ELO) in collaborative learning. Research in education 2002;31 (2/3):38-42].

\section{De auteurs:}

Drs. R.F.M. Turk was ten tijde van dit onderzoek wetenschappelijk docent bedrijfsgeneeskunde, afdeling Maatschappelijke Gezondheidszorg, Erasmus MC Rotterdam en is vanaf 1-9-09 hoofd van de afdeling Sociaal Medische Zorg van de GGD te Den Haag.

Drs. M.E.W. Dankbaar is programmamanager e-learning, Desiderius School, Erasmus MC Rotterdam.

Drs. E.F. van Beeck is universitair hoofddocent Public Health, afdeling Maatschappelijke Gezondheidszorg, Erasmus MC Rotterdam.

Correspondentieadres:

Drs. R.F.M. Turk; e-mail:r.turk@ocw.denhaag.nl

Belangenconflict: geen gemeld

Financiële ondersteuning: geen gemeld

\section{Summary}

Introduction: To evaluate the introduction of Computer Supported Learning to promote self-directed collaborative learning during clerkships when students are isolated from each other and from their teachers.

Methods: We developed a digital platform to enable subgroups of students to collaborate in solving practice-based problems and produce evidence-based papers and presentations on those problems. Furthermore all students were individually asked to write a peer review of a paper written by another subgroup. We evaluated the experiences of 141 students during two different phases, using a written questionnaire.

Results: A total of 124 students responded to the questionnaire (response rate 88\%). According to $65 \%$ of the respondents the problems that were presented were interesting. The collaboration in the group was described as good (94\%) and all members contributed equally (90\%). Of the respondents, $48 \%$ said they had learned from collaborating, from writing the peer review (63\%) and from the review of their own paper (64\%). In the first phase only $33 \%$ thought the digital platform made a positive contribution. In the second phase, in which we added a wiki to the platform, this percentage rose to $49 \%$. Supplementary comments were made on the time-schedule, the clarity and scope of the problems and the digital platform. The mean time spent per student was 10 hours.

Conclusion: Computer support can stimulate collaborative self-directed learning in situations where students are isolated from each other and from their teachers, but further measures are needed to stimulate collaboration. Setting, user-friendliness and timing are important factors for the success of the intervention. (Turk RFM, Dankbaar MEW, Beeck EF van. Introducing and evaluating Computer Supported Collaborative Learning during clerkships. Dutch Journal of Medical Education 2009;28(6):269-279.) 